Cite this: Phys. Chem Chem Phys. 2016, 18, 24401

Received 6th June 2016,

Accepted 1st August 2016

DOI: $10.1039 / c 6 c p 03938 c$

www.rsc.org/pccp

\title{
The photoenhanced aging process of soot by the heterogeneous ozonization reaction $\dagger$
}

\author{
Chong Han, ${ }^{\mathrm{ab}}$ Yongchun Liu ${ }^{\mathrm{ac}}$ and Hong He*ac
}

The atmospheric aging of soot can significantly modify its composition and microstructure, likely leading to changes in its effects on climate and health. The photochemical aging process of soot by $\mathrm{O}_{3}$ under simulated sunlight was investigated using in situ attenuated total internal reflection infrared spectroscopy. Simulated sunlight could markedly enhance the aging of soot by $\mathrm{O}_{3}$, which produced various oxygen containing species such as lactones, anhydrides, ketones and aldehydes. Elemental carbon (EC) showed minor reactivity toward $\mathrm{O}_{3}$. The organic carbon $(\mathrm{OC})$, which was mainly composed of various polycyclic aromatic hydrocarbons (PAHs) and some unidentified components, played a key role in the photochemical aging of soot by $\mathrm{O}_{3}$. The kinetics of aromatic species on soot can be well described by a pseudo-first order reaction. The fitting results of the pseudo first-order rate constant $\left(k_{1, \text { obs }}\right)$ as a function of $\mathrm{O}_{3}$ concentration demonstrated that the photochemical reaction of soot with $\mathrm{O}_{3}$ followed the Langmuir-Hinshelwood mechanism.

\section{Introduction}

Soot particles, which derive from the incomplete combustion of fossil fuels and biomass, are generally composed of elemental carbon (EC) and organic carbon (OC). ${ }^{1,2}$ They play an important role in global climate change. The global greenhouse effect of soot has been estimated to be the second strongest after $\mathrm{CO}_{2}$ due to the absorption of radiation, which directly influences the radiative budget of the atmosphere. ${ }^{3-5}$ They can also affect the precipitation by serving as cloud condensation nuclei (CCN). ${ }^{5}$ However, there is great uncertainty in the climatic impacts of soot since its morphology, composition and structure can be significantly changed during the atmospheric aging process. ${ }^{6-9}$

Over the past several decades, most studies have focused on the uptake kinetics of $\mathrm{O}_{3}$ on soot because of its potential contribution to $\mathrm{O}_{3}$ consumption in the upper troposphere and lower stratosphere. ${ }^{10-19}$ However, a rapid deactivation of soot was usually observed under dark conditions due to the depletion of reactive sites, suggesting that the reactivity of soot

\footnotetext{
${ }^{a}$ Research Center for Eco-Environmental Sciences, Chinese Academy of Sciences, Beijing, 100085, China. E-mail: honghe@rcees.ac.cn; Fax: +86-10-62923563; Tel: $+86-10-62849123$

${ }^{b}$ School of Metallurgy, Northeastern University, Shenyang, 110819, China

${ }^{c}$ Center for Excellence in Urban Atmospheric Environment, Institute of Urban Environment, Chinese Academy of Sciences, Xiamen 361021, China

$\dagger$ Electronic supplementary information (ESI) available: Fitting results for ATR-IR spectra of aged soot in the range of $1850-1500 \mathrm{~cm}^{-1}$. Changes of the IR spectra of elemental carbon aged by $\mathrm{O}_{3}$. Reactivity of dried soot residues after $n$-hexane extraction toward $\mathrm{O}_{3}$. Temporal changes of integrated areas of Ar-H. See DOI: $10.1039 / \mathrm{c} 6 \mathrm{cp} 03938 \mathrm{c}$
}

was too low to affect gas-phase $\mathrm{O}_{3}$ concentrations. Recently, it was found that ultraviolet light can significantly enhance the uptake of $\mathrm{O}_{3}$ on various organic molecules such as benzophenone, phenol, pyrene and humic acids. ${ }^{20-22}$ There may be some photosensitive compounds on soot, so light may also promote the heterogeneous reactivity of soot with trace gas species such as $\mathrm{NO}_{2}$ and $\mathrm{O}_{3}$. Indeed, Monge et al. have demonstrated a strong enhancing effect of ultraviolet light on the uptake of $\mathrm{NO}_{2}$ on the soot surface. ${ }^{23}$ Upon irradiation, the reactivity of soot toward $\mathrm{NO}_{2}$ remained persistent over several hours in contrast to measurements in the dark. ${ }^{23}$ Zelenay et al. have found that passivated soot was shown to be reactivated under irradiation with a 4-fold higher steady-state $\mathrm{O}_{3}$ uptake rate as compared to that in the dark. ${ }^{24}$

At present, little is known regarding how soot participates and what modification of soot takes place during these aging processes. Only a few reports have investigated the changes of composition and microstructure of soot during the reaction with $\mathrm{O}_{3}$ in the dark or under irradiation. ${ }^{2,6,24}$ Using infrared spectroscopy, it was detected that the reaction with $\mathrm{O}_{3}$ in the dark led to the decrease in organic carbon in soot, with a corresponding increase in ketone, lactone, and anhydride species. $^{2}$ UV/Vis light could enhance the decrease of aromatic and aliphatic carbon as soot was exposed to $\mathrm{O}_{3} \cdot{ }^{24}$ It should be pointed out that the heterogeneous aging process of soot by $\mathrm{O}_{3}$ under irradiation has not been entirely clear.

In this work, in situ attenuated total internal reflection infrared (ATR-IR) spectroscopy was used to investigate the heterogeneous aging of soot by $\mathrm{O}_{3}$ under simulated sunlight. It was observed that the photoenhanced aging of soot by $\mathrm{O}_{3}$ 
generated various oxygen-containing species, followed by the consumption of aromatic compounds. The reactivity of elemental carbon and organic carbon in soot toward $\mathrm{O}_{3}$ was examined via the heating and extraction experiments. The aging kinetics of soot by $\mathrm{O}_{3}$ were also analyzed in detail.

\section{Experimental section}

\subsection{Soot production}

Soot was produced by the combustion of $n$-hexane (AR, Sinopharm Chemical Reagent Lo., Ltd) in a co-flow diffusion burner, which has been described in our previous reports. ${ }^{25-27}$ The burner consisted of a diffusion flame maintained by an airflow, which could be exactly controlled using mass flowmeters. The airflow was a mixture of high purity oxygen and nitrogen, and the oxygen content was $21.5 \%$. The fuel transport was achieved using a cotton wick extending into the liquid fuel reservoir. The fuel/ oxygen ratio was expressed as the molar ratio of the consumed fuel to the introduced oxygen, and was fixed to be 0.10 .

\subsection{Aging experiment of soot}

The in situ ATR-IR spectra were recorded using a NEXUS 6700 spectrometer (Thermo Nicolet Instrument Corp.), a Fourier transform infrared (FT-IR) spectrometer equipped with a highsensitivity mercury-cadmium-telluride (MCT) detector cooled by liquid nitrogen and an attenuated total internal reflection infrared (ATR-IR) cell. Soot particles from the diffusion flame were directly deposited onto the ZnSe crystal of the ATR-IR cell, which flitted very fast within the same time (2-3 seconds) at $4 \mathrm{~cm}$ over the flame during soot deposition. The mass of soot deposited on the ZnSe crystal was very small compared to that of the ATR-IR cell, and thus it cannot be measured due to the limitation of measurement technique. A quartz glass was used to seal the ATR-IR cell. A xenon lamp of $500 \mathrm{~W}$ with continuous emission in the 350-700 $\mathrm{nm}$ range and a dominant wavelength at $480 \mathrm{~nm}$ was employed to simulate sunlight. The spectra of the xenon lamp and sunlight are similar and have been compared elsewhere. ${ }^{28-30}$ The irradiation intensity at the soot surface was $25 \mathrm{~mW} \mathrm{~cm}^{-2}$. Before the reaction with $\mathrm{O}_{3}$, the soot was purged by $100 \mathrm{~mL} \min ^{-1} \mathrm{~N}_{2}$ for $1 \mathrm{~h}$ at $298 \mathrm{~K}$. Then, $\mathrm{O}_{3}$ (100 ppb-2 ppm) was introduced into the ATR-IR cell, with a total flow rate of $100 \mathrm{~mL} \mathrm{~min}^{-1}$. The $\mathrm{O}_{3}$ was generated by irradiating a mixed flow of high purity $\mathrm{O}_{2}$ and $\mathrm{N}_{2}$ using a mercury lamp with emission wavelengths of 185 and $254 \mathrm{~nm}$. The concentration of $\mathrm{O}_{3}$ was measured using an ozone monitor (Model 202, 2B Technology). The spectra of soot were recorded (100 scans, $4 \mathrm{~cm}^{-1}$ resolution) using the blank ZnSe crystal as the reference. The experiments were carried out at $298 \mathrm{~K}$ under atmospheric pressure.

\subsection{Reactions of elemental carbon and organic carbon with $\mathrm{O}_{3}$}

To remove organic carbon (OC) without modifying the bulk elemental carbon (EC), fresh soot was heated to $300{ }^{\circ} \mathrm{C}$ in pure $\mathrm{N}_{2} \cdot{ }^{2}$ After being ultrasonically dispersed in $\mathrm{H}_{2} \mathrm{O}$, soot was deposited on the ZnSe crystal and purged by $100 \mathrm{~mL} \min ^{-1} \mathrm{~N}_{2}$. When the absorption peaks of $\mathrm{H}_{2} \mathrm{O}$ were no longer observed, $\mathrm{O}_{3}$ was introduced and infrared spectra were recorded. In addition, the ultrasonic extraction of fresh soot was also performed in $n$-hexane, which easily volatilizes due to its low boiling point and shows no reactivity towards $\mathrm{O}_{3}$ under simulated sunlight. To avoid the oxidation of the organic components, the extractions were carried out for $10 \mathrm{~min}$ in the dark. The reactivity of the extracts from fresh soot and the corresponding dried soot residues toward $\mathrm{O}_{3}$ was examined in the ATR-IR cell after evaporating the solvent.

\subsection{GC-MS analysis}

The compositions of the extracts of fresh soot and soot aged by $\mathrm{O}_{3}$ were analyzed using GC-MS. The column was a HP 5MS (internal diameter $0.25 \mathrm{~mm}$, length $30 \mathrm{~m}$, and film thickness $0.25 \mu \mathrm{m})$. The injection volume of the sample was $1 \mu \mathrm{L}$. The inlet temperature was $280{ }^{\circ} \mathrm{C}$. The temperature program for the analysis has been described in our previous studies. ${ }^{25,31}$ The interface temperature was maintained at $280{ }^{\circ} \mathrm{C}$ during the analysis.

\section{Results and discussion}

\subsection{Compositional changes of soot by ozonization}

Fig. 1 shows typical ATR-IR spectra of fresh soot (black line) and soot aged by $\mathrm{O}_{3}$ in the dark (blue line) and under simulated sunlight (red line). The band at $3038 \mathrm{~cm}^{-1}$ was related to the aromatic $\mathrm{C}-\mathrm{H}(\mathrm{Ar}-\mathrm{H})$ stretching vibration, while the three bands at 880,840 , and $754 \mathrm{~cm}^{-1}$ were ascribed to the modal vibration of substituted aromatic compounds. ${ }^{32-34}$ The peak at $1440 \mathrm{~cm}^{-1}$ was derived from the unsaturated $\mathrm{CH}_{2}$ scissor vibration. ${ }^{32}$ Several oxygen containing functional groups were also detected. The main characteristic band at $1594 \mathrm{~cm}^{-1}$ was assigned to carbonyl groups bonded to an aromatic ring $(\mathrm{Ar}-\mathrm{C}=\mathrm{O}){ }^{2,33-35}$ Another carbonyl group at $1722 \mathrm{~cm}^{-1}$ was attributed to ketone species $(\mathrm{C}=\mathrm{O}) .{ }^{2,33}$

After exposure to $\mathrm{O}_{3}$ for $20 \mathrm{~h}$, the surface species on soot exhibited obvious changes. As shown in Fig. 1, the peak intensity of $\mathrm{Ar}-\mathrm{H}\left(3038 \mathrm{~cm}^{-1}\right)$ decreased remarkably, whereas it is greatly increased for $\mathrm{C}=\mathrm{O}\left(1722 \mathrm{~cm}^{-1}\right)$ and $\mathrm{Ar}-\mathrm{C}=\mathrm{O}\left(1594 \mathrm{~cm}^{-1}\right)$.

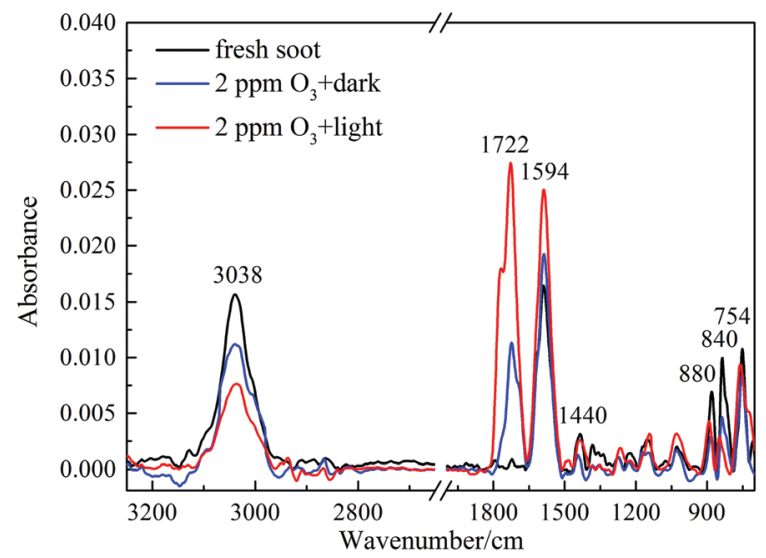

Fig. 1 ATR-IR spectra of fresh soot and soot aged by $\mathrm{O}_{3}(2 \mathrm{ppm})$ for $20 \mathrm{~h}$ in the dark and under simulated sunlight. 

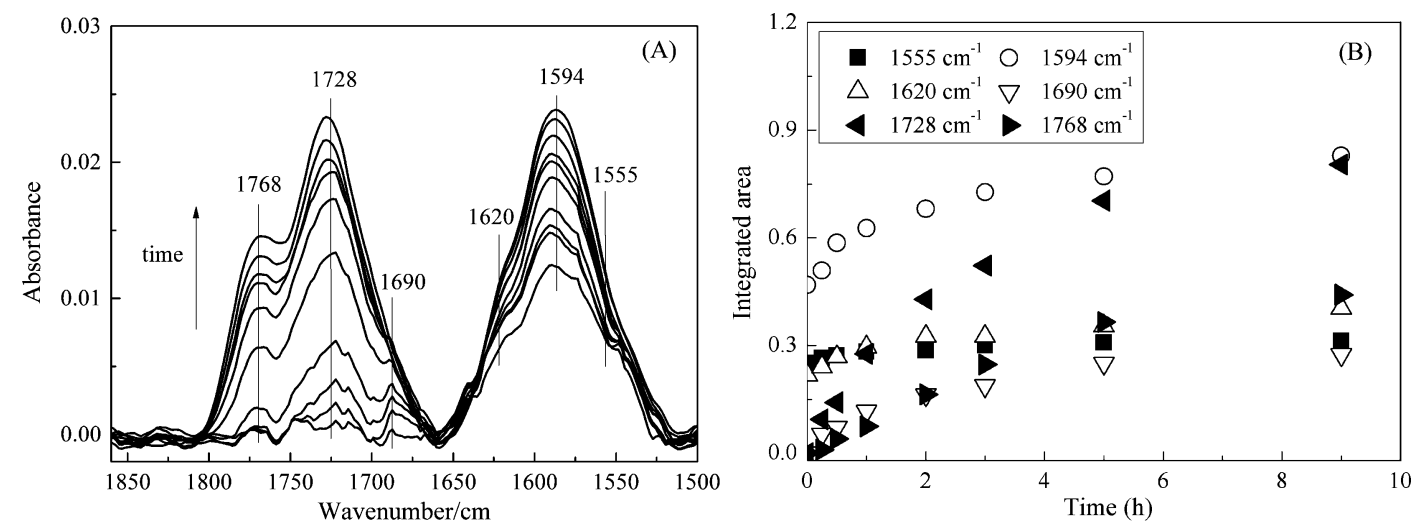

Fig. 2 Temporal changes of ATR-IR spectra in the range of $1850-1500 \mathrm{~cm}^{-1}$ for soot exposed to $2 \mathrm{ppm} \mathrm{O}_{3}$ under simulated sunlight (A) and temporal changes in the integrated areas of peaks at $1768,1728,1690,1620$ and $1594 \mathrm{~cm}^{-1}$ (B).

In particular, the ozonized soot under simulated sunlight displayed more significant changes in the peaks at 3038, 1722 and $1594 \mathrm{~cm}^{-1}$ than that in the dark. This definitely demonstrates that simulated sunlight can dramatically enhance the heterogeneous aging of soot by $\mathrm{O}_{3}$. Zelenay et al. also observed the role of UV/Vis light in enhancing the reaction of soot with $\mathrm{O}_{3}$ using NEXAFS spectra, in which the absorption bands for aromatic and aliphatic carbon decreased for soot exposed to both $\mathrm{O}_{3}$ and light. ${ }^{24}$

Fig. 2A displays temporal changes of ATR-IR spectra in the range of $1850-1500 \mathrm{~cm}^{-1}$ when fresh soot was exposed to $\mathrm{O}_{3}$ under simulated sunlight. Several overlapping peaks in Fig. 2A were identified and analyzed. These peaks were ascribed to oxygen-containing groups, including aliphatic $\mathrm{C}=\mathrm{O}$ such as lactones or anhydrides $\left(1768 \mathrm{~cm}^{-1}\right)$, ketones $\left(1728 \mathrm{~cm}^{-1}\right)$ and aldehydes $\left(1690 \mathrm{~cm}^{-1}\right)$, and aromatic $\mathrm{C}=\mathrm{O}(\mathrm{Ar}-\mathrm{C}=\mathrm{O})$ such as aromatic aldehyde, aromatic ketone, and aromatic quinone $\left(1620,1594\right.$ and $\left.\left.1555 \mathrm{~cm}^{-1}\right)\right)^{2,32-35}$ To obtain the integrated areas, the curve fitting was performed and is summarized in Fig. S1 (ESI $\dagger$ ). Fig. 2B shows the dynamic changes of integrated areas for peaks at 1768, 1728, 1690, 1620, 1594 and $1555 \mathrm{~cm}^{-1}$. The integrated areas of lactones or anhydrides $\left(1768 \mathrm{~cm}^{-1}\right)$, ketones $\left(1728 \mathrm{~cm}^{-1}\right)$, aldehydes $\left(1690 \mathrm{~cm}^{-1}\right)$, and $\mathrm{Ar}-\mathrm{C}=\mathrm{O}$ (1620, 1594 and $1555 \mathrm{~cm}^{-1}$ ) continuously increased with irradiation time. These results confirm that the photochemical aging of soot by $\mathrm{O}_{3}$ produces various oxygen containing compounds and their concentrations increase with irradiation time, which results in an increase in the $\mathrm{O} / \mathrm{C}$ atomic ratio of soot.

\subsection{Reactivity of elemental carbon and organic carbon towards $\mathrm{O}_{3}$}

It is well known that soot mainly consists of elemental carbon (EC) and some organic carbon (OC), the reactivity of which was examined by heating and extraction experiments. EC can be obtained by heating fresh soot at $300{ }^{\circ} \mathrm{C}$ in pure $\mathrm{N}_{2}$ to cause the loss of OC. ${ }^{2}$ After being exposed to $\mathrm{O}_{3}$ under simulated sunlight, only slight changes in the peaks at $\mathrm{Ar}-\mathrm{H}\left(3038 \mathrm{~cm}^{-1}\right), \mathrm{C}=\mathrm{O}\left(1729 \mathrm{~cm}^{-1}\right)$ and $\mathrm{Ar}-\mathrm{C}=\mathrm{O}\left(1594 \mathrm{~cm}^{-1}\right)$ were observed in the ATR-IR spectra of EC (Fig. S2, ESI $†$ ). This suggests that EC showed a minor photochemical reactivity toward $\mathrm{O}_{3}$.

OC usually includes various saturated and unsaturated hydrocarbons, polycyclic aromatic hydrocarbons (PAHs), and partially oxidized organic compounds. ${ }^{2,36,37}$ On the basis of thermal gravimetric analysis (TGA), the OC content of fresh soot was measured to be $34.4 \mathrm{mg} \mathrm{g}^{-1}$. When exposed to $\mathrm{O}_{3}$ under simulated sunlight, the extracts derived from the extraction of fresh soot in $n$-hexane exhibited a great decrease in the peak of $\mathrm{Ar}-\mathrm{H}\left(3038 \mathrm{~cm}^{-1}\right)$ as well as an obvious increase in the peaks of $\mathrm{C}=\mathrm{O}\left(1769,1720\right.$ and $\left.1685 \mathrm{~cm}^{-1}\right)$ and $\mathrm{Ar}-\mathrm{C}=\mathrm{O}$ (1628 and $1594 \mathrm{~cm}^{-1}$ ) in the ATR-IR spectra (Fig. 3). These were the same as the changes on the fresh soot after the reaction with $\mathrm{O}_{3}$ under irradiation. After being extracted by $n$-hexane, when the dried soot residue reacted with $\mathrm{O}_{3}$ under simulated sunlight, it only showed a weak increase of peaks assigned to carbonyl $\mathrm{C}=\mathrm{O}$ (Fig. S3, ESI $\dagger$ ), indicating its very low reactivity toward $\mathrm{O}_{3}$. These results confirm that the photochemical aging of soot by $\mathrm{O}_{3}$ primarily results from the ozonization of OC. In addition, $\mathrm{OC}$ was also a main contributor to the aging of soot by $\mathrm{O}_{2}$ and $\mathrm{NO}_{2}$ under irradiation. ${ }^{25,31}$

The compositions of the $n$-hexane extracts from fresh and ozonized soot were examined by GC-MS. As shown in Fig. 4, the extracts predominantly consisted of PAHs with 3-5 rings including anthracene, phenanthrene, $4 H$-lyclopenta[def $]$ phenanthrene, fluoranthene, pyrene, benzo[ghi]fluoranthene,

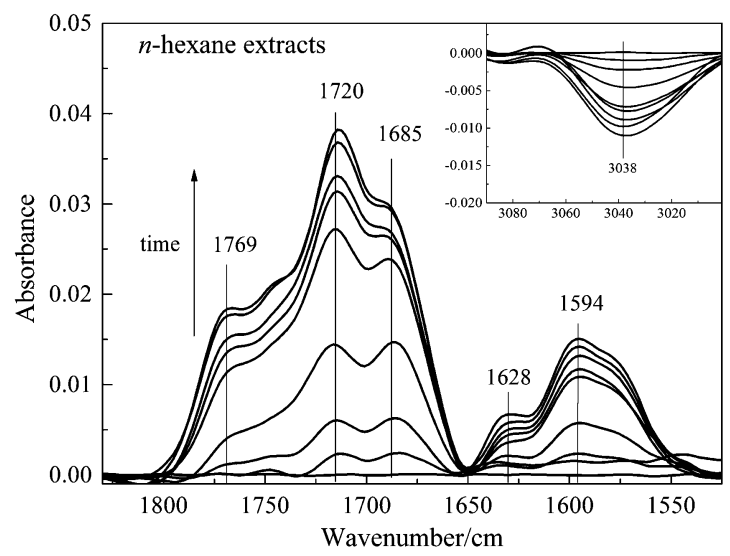

Fig. 3 Temporal changes of ATR-IR spectra in the range of $1800-1550 \mathrm{~cm}^{-1}$ (The inset corresponds to ATR-IR spectra in the range of $3090-3000 \mathrm{~cm}^{-1}$ ) for $n$-hexane extracts from fresh soot toward $\mathrm{O}_{3}(2 \mathrm{ppm})$ under simulated sunlight. 

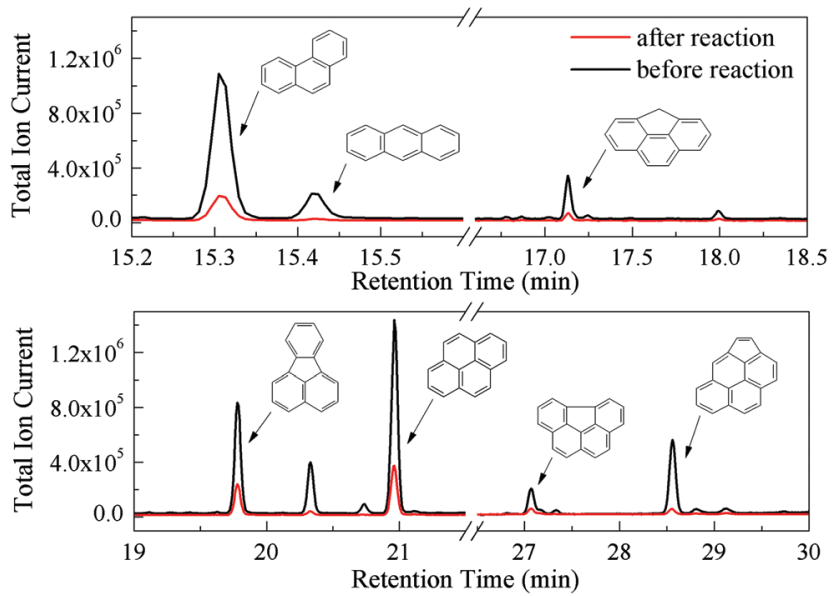

Fig. 4 Total ion chromatogram of the $n$-hexane extracts of fresh soot and soot aged by $\mathrm{O}_{3}(4 \mathrm{ppm}, 20 \mathrm{~h})$ under simulated sunlight.

cyclopenta $[c d]$ pyrene, and some unidentified compounds. After the reaction of soot with $\mathrm{O}_{3}$, the amount of PAHs mentioned above greatly decreased, which coincided with the decrease in $\mathrm{Ar}-\mathrm{H}$ in the ART-IR spectra. Using aerosol mass spectrometry, Antiñolo et al. also observed that PAH-like species within the soot particles decayed upon ozone exposure in the dark. ${ }^{38}$ This determines that PAHs play important roles in the photochemical aging of soot by $\mathrm{O}_{3}$. PAHs can absorb sunlight due to their extensive $\pi$-orbital systems. ${ }^{39}$ The enhanced uptake of $\mathrm{O}_{3}$ on benzophenone, pyrene and humic acid has been reported under ultraviolet light irradiation. $^{20-22}$ The degradation of organic compounds by the reaction with $\mathrm{O}_{3}$, including veratraldehyde, 4-phenoxyphenol and 3,4,5-trimethoxybenzaldehyde, was also photoenhanced in the presence of ultraviolet or visible light. ${ }^{40,41}$

\subsection{Reaction kinetics of soot with $\mathrm{O}_{3}$}

According to the experimental results, an electron transfer reaction may happen between adsorbed $\mathrm{O}_{3}$ and electronically excited species such as PAHs and aromatic structures with carbonyl functional groups, which likely contributes to the enhanced aging of soot by $\mathrm{O}_{3}$ under irradiation. A similar process has been proposed to explain the light-induced enhancement in the heterogeneous reaction of $\mathrm{O}_{3}$ with pyrene, ${ }^{21}$ which is an important reactant responsible for the photochemical aging of soot by $\mathrm{O}_{3}$ (Fig. 4).

The photodissociation of gas-phase $\mathrm{O}_{3}$ may generate some reactive species such as $\mathrm{O}\left({ }^{1} \mathrm{D}\right), \mathrm{O}\left({ }^{3} \mathrm{P}\right), \mathrm{O}_{2}\left(\mathrm{~b}^{1} \Sigma_{\mathrm{g}}{ }^{+}\right)$, and $\mathrm{O}_{2}\left(\mathrm{a}^{1} \Delta_{\mathrm{g}}\right),{ }^{42}$ which may cause the loss of $\mathrm{O}_{3}$ but also enhance the aging of soot. If the loss of gas-phase $\mathrm{O}_{3}$ is mainly attributed to its photodissociation when $\mathrm{O}_{3}$ is exposed to soot under irradiation, it will not depend on the reaction time and the soot mass. Nevertheless, it has been observed that the loss of $\mathrm{O}_{3}$ on soot under irradiation was dependent of the reaction time and the soot mass. ${ }^{24}$ This suggests that reactive species originating from the photodissociation of $\mathrm{O}_{3}$ should play a minor role in the loss of $\mathrm{O}_{3}$ and the aging of soot.

The Langmuir-Hinshelwood ( $\mathrm{L}-\mathrm{H})$ mechanism is usually employed to describe the heterogeneous reactions of materials with trace gases. ${ }^{43-45}$ This mechanism suggests that $\mathrm{O}_{3}$ is in rapid equilibrium between the gas phase and the surface, and the reaction then takes place among the adsorbed species. According to the $\mathrm{L}-\mathrm{H}$ mechanism and experimental results, two possible reaction paths were proposed as follows:

$$
\begin{gathered}
\mathrm{O}_{3(\mathrm{~g})}+\mathrm{S} \underset{k_{-1}}{\stackrel{k_{1}}{\longrightarrow}} \mathrm{O}_{3(\mathrm{ads})} \\
\mathrm{O}_{3(\mathrm{ads})}+\mathrm{R} \underset{k_{2}}{\stackrel{h \nu}{\longrightarrow}} \mathrm{P}
\end{gathered}
$$

where $\mathrm{S}$ is surface adsorption sites, $\mathrm{R}$ is surface reactive species, $\mathrm{O}_{3(\mathrm{~g})}$ is gaseous $\mathrm{O}_{3}, \mathrm{O}_{3(\mathrm{ads})}$ is adsorbed $\mathrm{O}_{3}$, and $\mathrm{P}$ is the product. The reaction rate of surface reactive species is described by eqn (3),

$$
\frac{\mathrm{d}[\mathrm{R}]}{\mathrm{d} t}=-k_{2} \times\left[\mathrm{O}_{3(\mathrm{ads})}\right] \times[\mathrm{R}]
$$

where $k_{2}$ is the second-order rate constant, and $t$ is the reaction time. Assuming that the concentration of adsorbed $\mathrm{O}_{3}$ remains constant when the soot surface changes after the reaction, a pseudo first-order reaction can be assumed using eqn (4),

$$
\frac{\mathrm{d}[\mathrm{R}]}{\mathrm{d} t}=-k_{1, \mathrm{obs}} \times[\mathrm{R}],
$$

where $k_{1, \text { obs }}=k_{2} \times\left[\mathrm{O}_{3(\mathrm{ads})}\right]$ is the pseudo first-order rate constant. If the integrated areas of the peaks in the ATR-IR spectra are directly proportional to the surface concentration, $[\mathrm{R}]$ can be replaced by the integrated areas.

As seen in Fig. S4 (ESI $\dagger$ ), the evolutions of the integrated areas for aromatic compounds (Ar-H, 3118-2950 $\left.\mathrm{cm}^{-1}\right)$ exhibited an exponential decrease pattern with time, indicating that the reaction may be described by the pseudo first-order kinetics. Ar-H was not completely consumed and reached a plateau after the reaction with $\mathrm{O}_{3}$ for $8 \mathrm{~h}$. It likely means that some $\mathrm{Ar}-\mathrm{H}$, which were not accessible to $\mathrm{O}_{3}$ and thus did not participate in the reaction, should not be considered in the determination of the reaction rate constant. The mass of soot may affect the accessibility of the active sites for $\mathrm{O}_{3}$, because the soot thickness may influence the diffusion of $\mathrm{O}_{3}$ into inner layers of the soot. If the aging of soot by $\mathrm{O}_{3}$ is a diffusionlimited process, one soot sample should not exhibit different reactivities in the dark and under irradiation (Fig. S4, ESI $\dagger$ ). Different functional groups in one soot sample also show different change trends as they are exposed to $\mathrm{O}_{3}$ (Fig. 2), further indicating that the aging of soot by $\mathrm{O}_{3}$ is not a diffusion controlling process.

The data of the integrated area were fitted using a pseudo first-order exponential function as shown in eqn (5), ${ }^{43,44}$

$$
\ln \left(\frac{A_{0}-A_{\mathrm{p}}}{A_{t}-A_{\mathrm{p}}}\right)=k_{1, \mathrm{obs}} t
$$

where $A_{t}$ is the peak area at time $t, A_{0}$ is the initial peak area, and $A_{\mathrm{p}}$ is the peak area at the plateau in Fig. S4 (ESI $\dagger$ ). A linear relationship between the natural logarithm of peak areas and time is displayed in Fig. 5, suggesting that the reaction of $\mathrm{Ar}-\mathrm{H}$ with $\mathrm{O}_{3}$ follows the pseudo first-order kinetics. The $k_{1 \text {,obs }}$ of $\mathrm{Ar}-\mathrm{H}$ was $(0.43 \pm 0.02) \mathrm{h}^{-1}$ in the dark, whereas it was $(0.77 \pm 0.07) \mathrm{h}^{-1}$ and larger by about $80 \%$ under simulated sunlight. This further demonstrates that sunlight can significantly enhance the aging of soot by $\mathrm{O}_{3}$. 


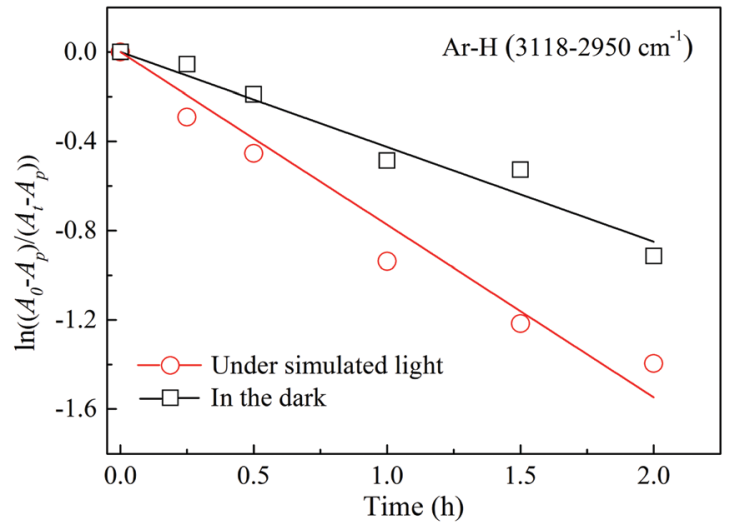

Fig. 5 Kinetics changes of $\mathrm{Ar}-\mathrm{H}\left(3118-2950 \mathrm{~cm}^{-1}\right)$ on soot during the aging process by $2 \mathrm{ppm} \mathrm{O}_{3}$ in the dark and under simulated sunlight.

Fig. 6 shows the changes of $k_{1 \text {,obs }}$ of $\mathrm{Ar}-\mathrm{H}$ as a function of $\mathrm{O}_{3}$ concentration. As expected, an enhancement of $k_{1, \mathrm{obs}}$ was observed when the $\mathrm{O}_{3}$ concentration was increased. This enhancement became less significant at high $\mathrm{O}_{3}$ concentration, which is consistent with the $\mathrm{L}-\mathrm{H}$ mechanism. The number of active sites on soot, which are available for the reaction with $\mathrm{O}_{3}$, is limited, so that the soot surface is saturated when a certain $\mathrm{O}_{3}$ concentration is reached. Assuming that the $\mathrm{O}_{3}$ adsorption on soot follows a Langmuir isotherm, $\theta_{\mathrm{O}_{3}}$, the fraction of active sites occupied by $\mathrm{O}_{3}$, is given by eqn (6),

$$
\theta_{\mathrm{O}_{3}}=\frac{K_{\mathrm{O}_{3}}\left[\mathrm{O}_{3}\right]_{\mathrm{g}}}{1+K_{\mathrm{O}_{3}}\left[\mathrm{O}_{3}\right]_{\mathrm{g}}}
$$

where $K_{\mathrm{O}_{3}}$ is the Langmuir adsorption constant of $\mathrm{O}_{3}$. The reaction rate of surface species can be written as eqn (7),

$$
\frac{\mathrm{d}[\mathrm{R}]}{\mathrm{d} t}=-k_{2} \times\left[\mathrm{O}_{3(\mathrm{ads})}\right] \times[\mathrm{R}]=-k_{2} \times\left[\mathrm{S}_{\mathrm{T}}\right] \times \theta_{\mathrm{O}_{3}} \times[\mathrm{R}],
$$

where $[S]_{T}$ is the total number of surface active sites. Substituting eqn (6) into eqn (7) yields

$$
\frac{\mathrm{d}[\mathrm{R}]}{\mathrm{d} t}=-\frac{k_{2}\left[\mathrm{~S}_{\mathrm{T}}\right] K_{\mathrm{O}_{3}}\left[\mathrm{O}_{3(\mathrm{~g})}\right]}{1+K_{\mathrm{O}_{3}}\left[\mathrm{O}_{3(\mathrm{~g})}\right]} \times[\mathrm{R}] .
$$

Therefore, $k_{1, \mathrm{obs}}$ can be expressed by eqn (9),

$$
k_{1, \mathrm{obs}}=\frac{k_{2}\left[\mathrm{~S}_{\mathrm{T}}\right] K_{\mathrm{O}_{3}}\left[\mathrm{O}_{3(\mathrm{~g})}\right]}{1+K_{\mathrm{O}_{3}}\left[\mathrm{O}_{3(\mathrm{~g})}\right]}
$$

The relationship between $k_{1 \text {,obs }}$ and $\mathrm{O}_{3}$ concentration was fitted according to eqn (9). As shown in Fig. 6A, the fitting results (solid line) determine that the heterogeneous photochemical aging of soot by $\mathrm{O}_{3}$ follows the $\mathrm{L}-\mathrm{H}$ mechanism. From the fitting results, the maximum reaction rate $\left(k_{2}\left[\mathrm{~S}_{\mathrm{T}}\right]\right)$ of $\mathrm{Ar}-\mathrm{H}$ and $K_{\mathrm{O}_{3}}$ was determined to be $(1.65 \pm 0.46) \mathrm{h}^{-1}$ and $(1.48 \pm 0.30) \times$ $10^{-14} \mathrm{~cm}^{3}$, respectively.

The reactive uptake coefficient of $\mathrm{O}_{3}\left(\gamma_{\mathrm{O}_{3}}\right)$ on soot under simulated sunlight was calculated by the following equation: ${ }^{44}$

$$
\gamma_{\mathrm{O}_{3}}=\frac{4 k_{1, \mathrm{obs}}}{\sigma \omega_{\mathrm{O}_{3}}\left[\mathrm{O}_{3(\mathrm{~g})}\right]}
$$

where $\sigma$ is the cross-section of soot particles, and its average value is estimated to be $7 \times 10^{-14} \mathrm{~cm}^{2},{ }^{27} \omega_{\mathrm{O}_{3}}$ is the mean molecular speed of $\mathrm{O}_{3}$ in the gas phase $\left(3.62 \times 10^{4} \mathrm{~cm} \mathrm{~s}^{-1}\right)$. Fig. 6B shows the plots of $\gamma_{\mathrm{O}_{3}}$ as a function of $\mathrm{O}_{3}$ concentration. When the $\mathrm{O}_{3}$ concentration was less than $500 \mathrm{ppb}$, the resulting $\gamma_{\mathrm{O}_{3}}$ values were on the order of $\sim 10^{-8}$, which was close to the previously reported value $\left(5.8 \times 10^{-8}\right)$ for $\mathrm{O}_{3}$ on soot after $60 \mathrm{~h}$ under irradiation. ${ }^{24}$ By substituting eqn (9) into eqn (10), the resulting eqn (11) can be used to fit the relationship between $\gamma_{\mathrm{O}_{3}}$ and the $\mathrm{O}_{3}$ concentration, as shown with the solid line in Fig. 6B.

$$
\gamma_{\mathrm{O}_{3}}=\frac{4 k_{2}\left[\mathrm{~S}_{\mathrm{T}}\right] K_{\mathrm{O}_{3}}}{\sigma \omega_{\mathrm{O}_{3}}\left(1+K_{\mathrm{O}_{3}}\left[\mathrm{O}_{3(\mathrm{~g})}\right]\right)}
$$

\section{Environmental implications}

The heterogeneous photochemical aging of soot by $\mathrm{O}_{3}$ may have significant effects on its physical and chemical properties
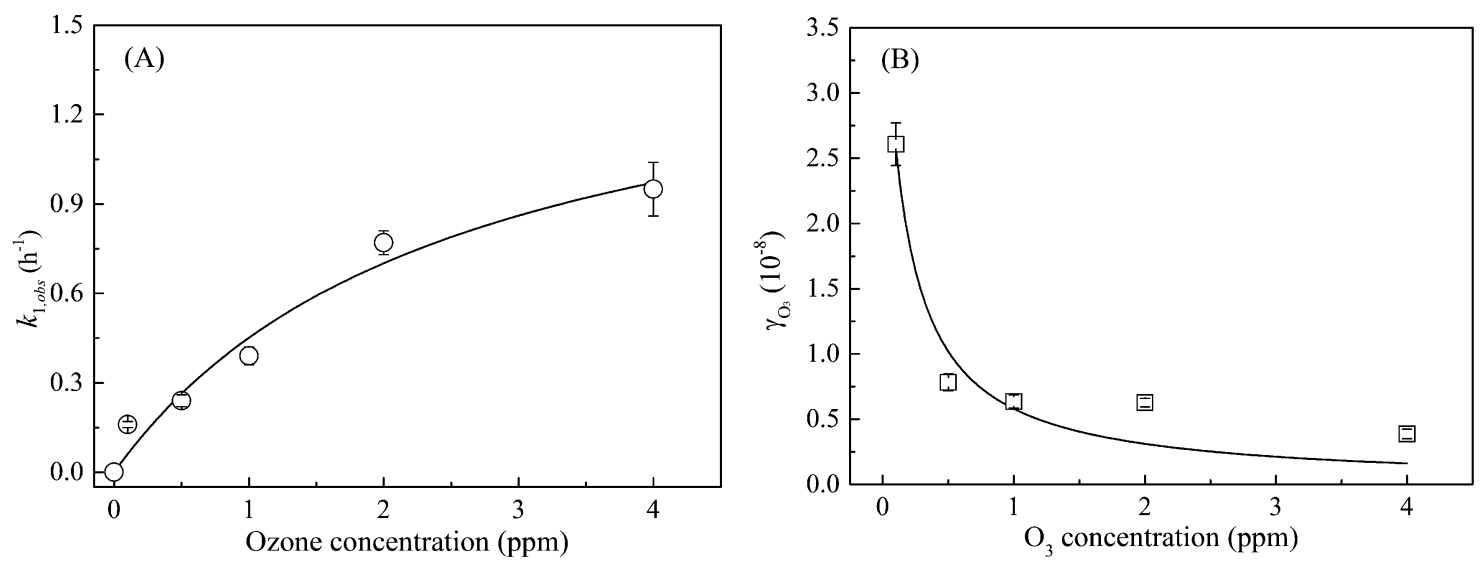

Fig. 6 (A) Changes of $k_{1, \text { obs }}$ of $\mathrm{Ar}-\mathrm{H}\left(3118-2950 \mathrm{~cm}^{-1}\right)$ as a function of $\mathrm{O}_{3}$ concentration. The data were fitted to eqn (9). (B) Uptake coefficients of $\mathrm{O}_{3}$ $\left(\gamma_{3}\right)$ calculated from $k_{1, \text { obs }}$ in graph (A) using eqn (10) as a function of $\mathrm{O}_{3}$ concentration. The data were fitted to eqn (11). 
in the atmosphere. The hygroscopicity of soot was directly related to the extent of surface oxidation. ${ }^{46}$ Liu et al. found that the ozonization reaction in the dark resulted in an enhancement of hygroscopicity of soot due to the formation of oxygencontaining surface species. ${ }^{6}$ Brooks et al. observed that exposure to ozone facilitated ice nucleation at warmer temperatures and increased heterogeneous nucleation rates on soot. ${ }^{47}$ Therefore, plenty of oxygen containing functional groups, which originated from the reaction of soot with $\mathrm{O}_{3}$ under simulated light, may significantly enhance the interaction of soot with water and promote the properties of soot as cloud condensation nuclei (CCN) and ice nuclei (IN). The atmospheric lifetime of aged soot may be also shortened via wet deposition.

Black carbon (BC) and light-absorbing organic carbon (brown carbon, BrC) play important roles in the earth's radiative balance. BrC can enhance BC's light absorption, which strongly depends on the ratio of $\mathrm{BrC}$ to $\mathrm{BC} \cdot{ }^{48-50}$ Moreover, Saleh et al. have reported that the contribution of $\mathrm{BrC}$ to light absorption is associated with its chemical compositions. ${ }^{50}$ According to our results, the $\mathrm{OC}$ components on soot aged by $\mathrm{O}_{3}$ under irradiation are greatly modified. This may change the solar absorption properties and warming effect of soot. It has been found that aged soot due to photooxidation showed a stronger light absorption than fresh soot. ${ }^{25}$

Soot particles also pose a health risk by causing and enhancing respiratory, cardiovascular, and allergic diseases. Recently, a few studies have investigated the changes in the toxicity of soot aged by $\mathrm{O}_{3} \cdot{ }^{38,51-53}$ As measured using dithiothreitol (DTT) assays, ozonized soot exhibits an increase in the redox cycling ability and toxicity compared to fresh soot. ${ }^{38,51-53}$ Antiñolo et al. have provided the mechanistic connection between the increased redox cycling ability of ozonized soot and its chemical composition, which involves a decrease in PAH-like species and an increase in quinones. $^{38}$ In this study, it is confirmed that PAHs on soot have a more significant decay upon ozone exposure under irradiation, with a corresponding increase in aromatic carbonyls. Thus, it is reasonable to deduce that the photochemical aging process of soot by $\mathrm{O}_{3}$ may markedly enhance the toxicity of soot.

\section{Conclusions}

Sunlight can dramatically enhance the heterogeneous aging process of soot by $\mathrm{O}_{3}$, leading to the formation of various oxygen-containing species such as lactones, anhydrides, ketones and aldehydes. Both the $300{ }^{\circ} \mathrm{C}$-heated soot and dried soot residues after being extracted by $n$-hexane exhibited little reactivity to $\mathrm{O}_{3}$, suggesting that $\mathrm{OC}$ should be the main contributor to the photochemical aging of soot by $\mathrm{O}_{3}$. Based on GC-MS analysis, OC mainly consisted of PAHs and some unidentified species, which were consumed during the photochemical aging of soot by $\mathrm{O}_{3}$. The kinetics of the reaction between $\mathrm{O}_{3}$ and $\mathrm{Ar}-\mathrm{H}$ on soot exhibited a pseudo first-order reaction behavior. Compared to the apparent rate constant $\left(k_{1, \mathrm{obs}}\right)$ of $\mathrm{Ar}-\mathrm{H}$ in the dark, $k_{1 \text {,obs }}$ increased by $80 \%$ under simulated sunlight. According to the relationship between $k_{1, \text { obs }}$ and $\mathrm{O}_{3}$ concentration, it is highly likely that the Langmuir-Hinshelwood mechanism is responsible for the photochemical aging of soot by $\mathrm{O}_{3}$.

\section{Acknowledgements}

This research was financially supported by the Strategic Priority Research Program of the Chinese Academy of Sciences (XDB05010301) and the National Natural Science Foundation of China (21190054, 91543109, and 21407020).

\section{References}

1 H. Muckenhuber and H. Grothe, Carbon, 2006, 44, 546-559.

2 H. M. Daly and A. B. Horn, Phys. Chem. Chem. Phys., 2009, 11, 1069-1076.

3 M. Z. Jacobson, Nature, 2001, 409, 695-697.

4 W. L. Chameides and M. Bergin, Science, 2002, 297, 2214-2215.

5 S. Menon, J. Hansen, L. Nazarenko and Y. Luo, Science, 2002, 297, 2250-2253.

6 Y. Liu, C. Liu, J. Ma, Q. Ma and H. He, Phys. Chem. Chem. Phys., 2010, 12, 10896-10903.

7 M. Knauer, M. E. Schuster, D. Su, R. Schlogl, R. Niessner and N. P. Ivleva, J. Phys. Chem. A, 2009, 113, 13871-13880.

8 H. Xue, A. F. Khalizov, L. Wang, J. Zheng and R. Zhang, Phys. Chem. Chem. Phys., 2009, 11, 7869-7875.

9 R. Zhang, A. F. Khalizov, J. Pagels, D. Zhang, H. Xue and P. H. McMurry, Proc. Natl. Acad. Sci. U. S. A., 2008, 105, 10291-10296.

10 D. M. Smith and A. R. Chughtai, J. Atmos. Chem., 1997, 26, 77-99.

11 H. Saathoff, S. Kamm, O. Mohler, K.-H. Naumann and U. Schurath, J. Aerosol Sci., 1998, 29, S889-S890.

12 Y. Bedjanian and M. L. Nguyen, Chemosphere, 2010, 79, 387-393.

13 T. Metts, S. Batterman, G. Fernandes and P. Kalliokoski, Atmos. Environ., 2005, 39, 3343-3354.

14 J. McCabe and J. P. D. Abbatt, J. Phys. Chem. C, 2009, 113, 2120-2127.

15 C.-F. Wei, S. M. Larson, K. O. Patten and D. J. Wuebbles, Atmos. Environ., 2001, 35, 6167-6180.

16 S. Bekki, J. Geophys. Res.: Atmos., 1997, 102, 10751-10758.

17 S. Kamm, O. Mohler, K.-H. Naumann, H. Saathoff and U. Schurath, Atmos. Environ., 1999, 33, 4651-4661.

18 Y.-B. Aklilu and D. V. Michelangeli, Environ. Sci. Technol., 2004, 38, 5540-5547.

19 A. R. Chughtai, J. M. Kim and D. M. Smith, J. Atmos. Chem., 2003, 45, 231-243.

20 A. Jammoul, S. Gligorovski, C. George and B. D’Anna, J. Phys. Chem. A, 2008, 112, 1268-1276.

21 S. A. Styler, M. Brigante, B. D'Anna, C. George and D. J. Donaldson, Phys. Chem. Chem. Phys., 2009, 11, 7876-7884.

22 B. D’Anna, A. Jammoul, C. George, K. Stemmler, S. Fahrni, M. Ammann and A. Wisthaler, J. Geophys. Res.: Atmos., 2009, 114, D12301.

23 M. E. Monge, B. D’Anna, L. Mazri, A. Giroir-Fendler, M. Ammann, D. J. Donaldson and C. George, Proc. Natl. Acad. Sci. U. S. A., 2010, 107, 6605-6609. 
24 V. Zelenay, M. E. Monge, B. D’Anna, C. George, S. A. Styler, T. Huthwelker and M. Ammann, J. Geophys. Res.: Atmos., 2011, 116, D11301.

25 C. Han, Y. Liu, J. Ma and H. He, Proc. Natl. Acad. Sci. U. S. A., 2012, 109, 21250-21255.

26 C. Han, Y. Liu and H. He, Environ. Sci. Technol., 2013, 47, 3174-3181.

27 C. Han, Y. Liu, C. Liu, J. Ma and H. He, J. Phys. Chem. A, 2012, 116, 4129-4136.

28 Y. Li, W.-N. Wang, Z. Zhan, M.-H. Woo, C.-Y. Wu and P. Biswas, Appl. Catal., B, 2010, 100, 386-392.

29 L. Duracher, L. Blasco, A. A. Jaoued, L. Vian and G. MartiMestres, Photochem. Photobiol., 2009, 85, 1459-1467.

30 A. B. Murphy, P. R. F. Barnes, L. K. Randeniya, I. C. Plumb, I. E. Grey, M. D. Horne and J. A. Glasscock, Int. J. Hydrogen Energy, 2006, 31, 1999-2017.

31 C. Han, Y. Liu and H. He, Atmos. Environ., 2013, 64, 270-276.

32 J. P. Cain, P. L. Gassman, H. Wang and A. Laskin, Phys. Chem. Chem. Phys., 2010, 12, 5206-5218.

33 U. Kirchner, V. Scheer and R. Vogt, J. Phys. Chem. A, 2000, 104, 8908-8915.

34 M. S. Akhter, A. R. Chughtai and D. M. Smith, Appl. Spectrosc., 1985, 39, 143-153.

35 H. A. Al-Abadleh and V. H. Grassian, J. Phys. Chem. A, 2000, 104, 11926-11933.

36 M. T. O. Jonker, S. B. Hawthorne and A. A. Koelmans, Environ. Sci. Technol., 2005, 39, 7889-7895.

37 M. T. O. Jonker and A. A. Koelmans, Environ. Sci. Technol., 2002, 36, 3725-3734.

38 M. Antinolo, M. D. Willis, S. Zhou and J. P. Abbatt, Nat. Commun., 2015, 6, 6812.

39 A. Mallakin, D. G. Dixon and B. M. Greenberg, Chemosphere, 2000, 40, 1435-1441.
40 S. Net, L. Nieto-Gligorovski, S. Gligorovski and H. Wortham, Atmos. Chem. Phys., 2010, 10, 1545-1554.

41 S. Net, S. Gligorovski and H. Wortham, Atmos. Environ., 2010, 44, 3286-3294.

42 P. O'Keeffe, T. Ridley, S. Wang, K. P. Lawley and R. J. Donovan, Chem. Phys. Lett., 1998, 298, 368-374.

43 J. Ma, Y. Liu and H. He, Atmos. Environ., 2011, 45, 917-924.

$44 \mathrm{~J} . \mathrm{Ma}, \mathrm{Y}$. Liu and H. He, Atmos. Environ., 2010, 44, 4446-4453.

45 J. Ma, Y. Liu, Q. Ma, C. Liu and H. He, Atmos. Environ., 2013, 72, 165-170.

46 A. R. Chughtai, G. R. Williams, M. M. O. Atteya, N. J. Miller and D. M. Smith, Atmos. Environ., 1999, 33, 2679-2687.

47 S. D. Brooks, K. Suter and L. Olivarez, J. Phys. Chem. A, 2014, 118, 10036-10047.

48 S. Liu, A. C. Aiken, K. Gorkowski, M. K. Dubey, C. D. Cappa, L. R. Williams, S. C. Herndon, P. Massoli, E. C. Fortner, P. S. Chhabra, W. A. Brooks, T. B. Onasch, J. T. Jayne, D. R. Worsnop, S. China, N. Sharma, C. Mazzoleni, L. Xu, N. L. Ng, D. Liu, J. D. Allan, J. D. Lee, Z. L. Fleming, C. Mohr, P. Zotter, S. Szidat and A. S. Prevot, Nat. Commun., 2015, 6, 8435.

49 R. Bahadur, P. S. Praveen, Y. Xu and V. Ramanathan, Proc. Natl. Acad. Sci. U. S. A., 2012, 109, 17366-17371.

50 R. Saleh, E. S. Robinson, D. S. Tkacik, A. T. Ahern, S. Liu, A. C. Aiken, R. C. Sullivan, A. A. Presto, M. K. Dubey, R. J. Yokelson, N. M. Donahue and A. L. Robinson, Nat. Geosci., 2014, 7, 647-650.

51 Q. Li, J. Shang and T. Zhu, Atmos. Environ., 2013, 81, 68-75.

52 A. L. Holder, B. J. Carter, R. Goth-Goldstein, D. Lucas and C. P. Koshland, Atmos. Pollut. Res., 2012, 3, 25-31.

53 R. D. McWhinney, S. S. Gao, S. Zhou and J. P. D. Abbatt, Environ. Sci. Technol., 2011, 45, 2131-2136. 